\title{
PENGARUH CUSTOMER SATISFACTION DAN MEMBERSHIP CARD LOYALTY TERHADAP STORE LOYALTY PADA INDUSTRI RITEL KATEGORI MINIMARKET DI JAKARTA
}

\author{
Januar Robin Stanley \\ Program Studi S2 MM Eksekutif Muda \\ Sekolah Tinggi Manajemen PPM \\ Pepey Riawati Kurnia \\ Sekolah Tinggi Manajemen PPM
}

\begin{abstract}
Industri ritel kategori minimarket di Indonesia saat ini sedang berkembang dalam persaingan yang ketat. Peritel minimarket di Indonesia memanfaatkan loyalty program berupa membership card untuk menjaga loyalitas konsumennya. Konsep loyalitas saat ini tidak hanya terbatas pada kesetiaan konsumen hanya pada salah satu gerai peritel, namun sudah berkembang hingga multi-loyalty. Dalam penelitian ini dilibatkan 115 responden di area Jakarta sebagai sample untuk mengukur pengaruh antara card perceived value dan card satisfaction terhadap card loyalty. Serta pengaruh antara card loyalty dan store satisfaction terhadap store loyalty. Selain meneliti tentang pengaruh antar variabel, penelitian ini juga menunjukkan harapan yang diinginkan terhadap program membership card, serta dampak membership card terhadap tindakan konsumen.Hasil penelitian menunjukkan bahwa card perceived value dan card satisfaction berpengaruh positif terhadap card loyalty. Card card perceived value memiliki pengaruh yang lebih besar dibandingkan dengan card satisfaction. Dalam pengukuran store loyalty, card loyalty dan store satisfaction berpengaruh positif terhadap store loyalty. Card loyalty memiliki pengaruh yang lebih besar dibandingkan store satisfaction.Hasil dari penelitian ini mengungkapkan bahwa konsumen banyak mengharapkan membership card yang juga dapat digunakan sebagai alat pembayaran. Serta memperoleh privilege dalam antrian dan informasi promosi. Selain itu, 25\% dari responden memiliki lebih dari 1 kartu keanggotaan. Kondisi ini menunjukkan keberadaan multi-loyalty pada konsumen minimarket di Jakarta.
\end{abstract}

Keywords:

Customer Satisfaction, Customer Loyalty 


\section{PENDAHULUAN}

Berdasarkan data Nielsen pada tahun 2011 jumlah gerai modern FMCG mencapai 11.811 gerai di Indonesia. Kompetisi bisnis dalam industri ritel fast moving consumer goods (FMCG) di Indonesia sedang berlangsung secara ketat. Data dari AC Nielsen Indonesia menunjukkan, peritel kelas minimarket paling mendominasi pasar industri ritel bila dilihat dari jumlah gerai yang ada. Pertumbuhan gerai minimarket mencapai $36,6 \%$ pada tahun 2010. Pada kelas minimarket di Indonesia, terdapat dua pemain besar yang mendominasi pasar secara nasional yaitu Indomaret dan Alfamart.

Berdasarkan hasil survey internal yang dilakukan oleh PT. Indomarco Prismatama (INDOMARET), menunjukkan bahwa terdapat 3134 gerai ritel minimarket di kota Jakarta. Dalam persaingan bisnis yang ketat, pelaku bisnis akan berupaya memperoleh loyalitas dari pelanggannya. Program membership card merupakan salah satu cara memberikan nilai tambah kepada konsumen sehingga meningkatkan loyalitas terhadap perusahaan (Buttle, 2004).

Program loyalitas hanya salah satu dari inisiatif kompetitif yang banyak digunakan oleh peritel untuk melengkapi senjata tradisional seperti merek, layanan pelanggan, harga, berbagai barang dagangan, promosi produk dan lokasi (Merlin Stone, 2003). Dengan loyalitas konsumen yang tinggi akan meningkatkan market share dalam menghadapi persaingan harga dalam kompetisi (Chaudhuri and Holbrook, 2001).

Menjalankan program loyalitas adalah tugas manajerial yang besar. Apa yang dilihat oleh konsumen seperti kartu, kupon, dan bonus poin hanyalah puncak gunung es. Di balik itu semua terletak operasi manajerial dan logistik yang besar serta melibatkan penerbit kartu, manajemen database, call center, negosiasi dengan mitra kerja dan pemasok barang dagangan (Merlin Stone, 2003).

Dalam upaya memperoleh loyalitas konsumen, perusahaan perlu fokus terhadap kepuasan konsumen serta perceived value yang ada dalam benak konsumen (Yang dan Peterson, 2004). Kepuasan pelanggan akan memberikan dampak positif terhadap performa perusahaan serta meningkatkan loyalitas pelanggan (Buttle, 2004).

Fenomena yang dapat diamati saat ini adalah, seorang konsumen dapat menjadi anggota dari beberapa program membership card sekaligus. Bagi pelaku bisnis ritel, keikutsertaan konsumen dalam beberapa program loyalitas dapat mengurangi manfaat dari masing - masing program tersebut (Mägi, 2003).

Dari penjelasan di atas, peneliti tertarik untuk mengetahui pengaruh customer satisfaction dan membership card loyalty terhadap store loyaty pada industri minimarket di Jakarta. Secara umum, hasil dari penelitian ini akan memberikan informasi yang bermanfaat bagi akademisi maupun pelaku ritel minimarket.

\section{TINJAUAN PUSTAKA}

\subsection{Customer Loyalty Program}

Loyalty program adalah program pemasaran yang dirancang untuk membangun loyalitas pelanggan dengan memberikan insentif pada pelanggan (Youjae Yi dan Hoseong Jeon, 2003).

Terdapat dua jenis loyalty program yaitu limited dan open. Limited loyalty program tidak dapat diikuti oleh setiap pelanggan karena untuk mengikuti loyalty program tipe limited maka pelanggan harus memenuhi prosedur tertentu yang ditetapkan perusahaan. Sementara itu, open loyalty program merupakan jenis loyalty program yang dapat diikuti oleh setiap pelanggan 
tanpa ada persyaratan tertentu yang harus dipenuhi.

Salah satu bentuk customer loyalty program yang sering digunakan adalah membership card. Keanggotaan merupakan suatu pengakuan sebagai pelangan yang bergabung dalam suatu organisasi, perusahaan atau kelompok secara resmi dan diakui. Penting untuk membuat pelanggan merasa menjadi satu individual ataupun anggota dari sebuah perusahaan (Gronroos, 2000). Keanggotaan biasanya ditandai dengan adanya sebuah member card.

Menurut Nunes dan Dreze (2008) beberapa hal yang dapat diperoleh peritel dari sebuah program loyalitas adalah sebagai berikut :

1. Meningkatkan share of wallet dari konsumen.

2. Mendorong konsumen untuk melakukan pembelanjaan tambahan.

3. Memahami pola perilaku dan pemilihan konsumen.

4. Meningkatkan keuntungan perusahaan.

\subsection{Customer Loyalty and Measurement}

Loyalitas didefinisikan sebagai suatu sikap yang terkadang melibatkan hubungan dengan merek. Dalam arti kedua, loyalitas bisa dilihat dari perilaku pembelian berulang (Uncle et al. 2003). Dalam pengertian ini, Dick dan Basu (1994) mendefinisikan loyalitas sebagai gabungan dari sikap positif dan berlangganan. Menurut Shellyana dan Dharmmesta (2002), loyalitas mempunyai pola pembelian ulang pada merek fokal yang merupakan loyalitas sesungguhnya atau loyalitas pada merek tunggal. Sehingga loyalitas pelanggan disini dapat diartikan sebagai loyalitas merek.

Karena konsumen dapat memiliki loyalitas terhadap lebih dari satu alternatif peritel, maka dapat dibedakan antara membership card loyalty dan store loyalty dalam konsep loyalitas pelanggan (Sunny $\mathrm{Hu}$ et al., 2010). Sedangkan definisi dari konsumen loyal adalah seseorang yang melakukan aktifitas membeli barang atau jasa yang memenuhi kriteria sebagai berikut (Griffin, 1995) :

1. Melakukan pembelian ulang secara berkala.

2. Membeli produk lain yang ditawarkan produsen yang sama.

3. Merekomendasikan produk atau jasa tersebut kepada orang lain.

Loyalitas adalah sikap dari konsumen dalam menentukan pilihannya untuk tetap menggunakan produk atau jasa dari suatu perusahaan. Sikap menentukan pilihan tersebut juga untuk membuat komitmen dan melakukan pembelian ulang pada perusahaan tersebut (Foster dan Cadogan, 2000).

Dimensionalisasi yang dipergunakan dalam mengukur konstruk loyalitas konsumen mengacu pada penelitian Bloemer, et al., (1998) dan Foster dan Cadogan (2000). Indikator yang akan digunakan adalah antara lain: rekomendasi, pembelian, pilihan pertama, dan Word of mouth.

\subsection{Multiple Loyalty}

Ehrenberg (1988) mencatat bahwa loyalitas pelanggan dapat dibagi di antara beberapa merek, yang mengarah ke multiple loyalty. Jika multiple loyalty adalah pendapat yang dapat diterima, maka loyalitas pelanggan dapat dibagi menjadi loyalitas terhadap program dan loyalitas terhadap merek atau gerai. Program loyalitas merupakan sikap loyal yang relatif tinggi condong ke arah program loyalitas, namun belum tentu sebanding dengan loyalitas terhadap merek atau penyedia program.

Program loyalitas mirip dengan studi yang pernah dilakukan oleh Yim dan Kannan (1999) mengenai loyalitas terhadap 
insentif. Pelanggan dapat memiliki loyalitas terhadap lebih dari satu alternatif (Yim dan Kannan 1999). Menurut Dowling dan Uncle (1997) konsumen dapat memilih beberapa merek berbeda karena alasan penggunaan tertentu atau karena mereka ingin beberapa variasi. Pemilihan kepada beberapa mereka juga bisa terjadi karena ada penawaran khusus yang menarik minat konsumen. Kebanyakan pembeli yang berubah dari satu merek tidak berarti tidak memiliki loyalitas.

\subsection{Customer Satisfaction and Measurement}

Dewasa ini perhatian kepada kepuasan maupun ketidakpuasan konsumen telah semakin besar, semakin banyak pihak yang menaruh perhatian terhadap hal ini. Terciptanya kepuasan konsumen dapat memberikan beberapa manfaat antara lain, hubungan antara perusahaan dan konsumen menjadi harmonis, memberikan dasar yang baik bagi pembelian ulang dan terciptanya loyalitas konsumen dan menguntungkan bagi perusahaan.

Selanjutnya Kotler (2009), dalam bukunya Marketing Management memberikan definisi "Customers satisfaction is a person's feeling of pleasure or dissapointment resulting from comparing from product's perceived performance (or outcome) in relation to his or her expectations". Pengukuran kepuasan (Kotler, 2009) dapat diukur dengan beberapa cara kepuasan dengan menanyakan secara langsung kepada konsumen dengan menggunakan skala. Metode lain dengan meminta konsumen membuat daftar masalah yang dihadapi dan membuat daftar yang disarankan untuk perbaikan. Dalam penelitian ini, customer satisfaction akan diperhatikan bukan hanya terhadap layanan yang diberikan namun juga kepada kepuasan konsumen terhadap program loyalty yang dibuat.
Metode survei merupakan metode yang paling banyak digunakan dalam pengukuran kepuasan pelanggan. Metode survei kepuasan pelanggan dapat menggunakan pengukuran dengan ciri sebagai berikut:

1. Pengukuran dapat dilakukan secara langsung dengan pertanyaan seperti "Ungkapkan seberapa puas saudara terhadap pelayanan yang diberikan pada skala berikut : sangat tidak puas, tidak puas, netral, puas, sangat puas" (directly reported satisfaction).

2. Responden diberi pertanyaan mengenai seberapa besar mereka mengharapkan suatu atribut tertentu dan seberapa besar yang mereka rasakan (derived dissatisfaction).

3. Responden diminta untuk menuliskan masalah-masalah yang mereka hadapi berkaitan dengan penawaran dari perusahaan. Disamping itu responden juga diminta untuk menuliskan perbaikanperbaikan yang mereka sarankan (problem analysis).

4. Responden dapat diminta untuk meranking berbagai elemen (atribut) dari penawaran berdasarkan derajat pertanyaan setiap elemen dan seberapa baik kinerja perusahaan dalam masingmasing elemen (importance/performance ratings).

Penelitian yang dilakukan oleh Parasuraman, Ziethmal dan Berry (1988), mengidentifikasikan bahwa terdapat sepuluh dimensi pokok kualitas layanan, yaitu bukti fisik, reliabilitas, respon, kompetensi, kesopanan, kredibilitas, keamanan, akses, komunikasi dan pemahaman terhadap konsumen. Penelitian lanjutan Parasuraman, Ziethmal dan Berry (1988), mengelompokkan dimensi komunikasi, kredibilitas, keamanan, kompetensi dan kesopanan disatukan ke dalam dimensi kepercayaan, sedangkan dimensi akses dan 
pemahaman konsumen disatukan ke dalam dimensi kepedulian. Dengan adanya penggabungan ini, maka untuk selanjutnya terdapat lima dimensi kualitas yang umum digunakan dalam mengukur kualitas layanan. Kelima dimensi tersebut adalah :

1. Tangible, yaitu tampilan fisik tempat pemberian layanan, perlengkapan kerja, sarana komunikasi dan penampilan dari pekerja.

2. Reliability, yaitu kemampuan untuk dapat memberikan layanan sesuai yang dijanjikan dengan cepat dan tepat.

3. Responsiveness, yaitu kemauan pekerja untuk selalu tanggap dalam membantu konsumen dalam pemberian layanan.

4. Assurance, yaitu kepercayaan atau kepastian atas pengetahuan dan kesopanan pekerja dan kepercayaan diri dari pekerja tersebut.

5. Emphaty, yaitu perhatian pekerja kepada pribadi konsumen serta berusaha untuk dapat mengerti kebutuhan dari konsumen.

\subsection{Customer Perceived Value and Measurement}

Customer Perceived Value (CPV)

adalah hasil evaluasi yang dilakukan calon konsumen terhadap manfaat dan biaya yang ditawarkan oleh suatu alternatif tertentu. Manfaat yang diharapkan konsumen merupakan meliputi aspek ekonomis, fungsi dan psikologis yang diperoleh dari produk, layanan, personil dan image. Biaya yang dirasakan oleh calon konsumen adalah kumpulan biaya yang muncul dalam proses evaluasi, upaya memperoleh, masa pemakaian dan proses membuang produk yang ditawarkan, hal ini termasuk harga produk, waktu, tenaga dan biaya psikologis (Kotler and Keller 2009). Di bidang pemasaran, konstruk dari perceived value telah diidentifikasi sebagai salah satu ukuran paling penting mendapatkan keunggulan kompetitif (Parasuraman, 1997), dan telah diperdebatkan sebagai indikator yang paling mempengaruhi niat pembelian kembali (Parasuraman \& Grewal, 2000).

Dalam proses mengukur CPV, Kotler and Keller (2009) menerapkan beberapa langkah berikut ini :

1. Identifikasi atribut dan manfaat yang diharapkan oleh konsumen.

2. Lakukan penelitian kualitatif untuk mengetahui tingkat kepentingan dari masing-masing atribut dan manfaat yang diharapkan oleh konsumen.

3. Temukan pandangan yang beragam dari konsumen mengenai performa perusahaan dan kompetitor berdasarkan tingkat kepentingan masing - masing atribut dan manfaat.

4. Temukanlah bagaimana konsumen dalam segmen yang spesifik memperkirakan performa perusahaan dibandingkan dengan kompetitor.

Dalam lingkup ritel, Sweeney dan Soutar (2001) mengembangkan skala untuk mengukur nilai yang disebut PERVAL. Skala PERVAL terdiri atas tiga dimensi dasar :

1. Nilai emosional (perasaan afektif dihasilkan oleh produk),

2. Nilai sosial (kemampuan produk untuk meningkatkan nilai sosial konsumen) dan

3. Nilai fungsional, terdiri dari sub-dimensi harga (penurunan biaya yang dirasakan jangka pendek dan jangka panjang) dan kualitas (kinerja produk).

Berdasarkan rerangka konsep penelitian ini dilaksanakan berdasarkan beberapa hipotesis berikut ini :

H1 : Membership Card Satisfaction berpengaruh positif pada Membership Card Loyalty.

H2 : Membership Card Perceived value berpengaruh positif pada loyalitas Membership Card Loyalty.

H3 : Membership Card Loyalty berpengaruh positif pada Store Loyalty. 
H4 : Store Satisfaction berpengaruh positif pada Store Loyalty.

\section{RANCANGAN PENELITIAN}

Data primer yang digunakan adalah data hasil kuisioner kepada responden dengan kriteria dan asumsi seperti dijelaskan berikut ini.

Kriteria yang digunakan :

1. Usia $20-34$ Tahun

Usia 20 - 34 tahun dipilih sebagai sampel karena merupakan kelompok usia dengan proporsi terbesar pada penduduk Jakarta. Selain itu menurut pengamatan pribadi peneliti, kelompok usia tersebut merupakan konsumen yang sering berkunjung ke gerai minimarket.

2. Merupakan anggota dari salah satu program membership card ritel minimarket di Jakarta dengan keanggotaan yang masih aktif

3. Berdomisili di Jakarta

Berdasarkan Tabel Krejie Morgan maka sample yang dibutuhkan adalah sebanyak 384 responden. Namun karena keterbatasan waktu dan dana maka peneliti akan membatasi sebanyak 115 responden. Pengambilan sample dibagi dalam 5 bagian area yaitu Jakarta Pusat, Jakarta Utara, Jakarta Selatan, Jakarta Timur dan Jakarta Barat dengan jumlah responden 23 orang untuk masing-masing area.

Dalam penelitian ini, terdapat beberapa variabel yang menjadi perhatian peneliti. Variabel Card Satisfaction $\left(\mathrm{X}_{1}\right)$ dan Card Perceived Value $\left(\mathrm{X}_{2}\right)$ sebagai variabel Independen serta variabel Card Loyalty ( $\mathrm{Y}_{1}$ atau $\mathrm{X}_{3}$ ) sebagai variabel Intervening. Selain 3 variabel tersebut, ada pula varible independen Store Satfisfaction $\left(\mathrm{X}_{4}\right)$ dan variabel dependen Store Loyalty $\left(\mathrm{Y}_{2}\right)$. Semua variabel diukur dengan 24 pertanyaan melalui kuisioner.

\section{HASIL DAN PEMBAHASAN}

\subsection{Profil Responden}

Responden yang terlibat dalam penelitian ini bila dilihat dari kelompok umur, terdiri dari 51 responden (44\%) berusia $25-29$ tahun, 50 responden (44\%) berusia 20 - 24 tahun dan 14 responden $(12 \%)$ berusia 30 - 34 tahun. Berdasarkan pengelompokkan pendidikan terakhir, 91 responden (79\%). Lulusan SMU sebanyak 22 orang (19\%), 1 orang lulusan SMP (1\%) dan 1 orang lulusan S2 (1\%). Responden terdiri dari 60 responden (52\%) Laki - laki dan 55 responden (48\%) perempuan.

Kartu Indomaret card di miliki oleh 67 orang responden yang terdiri dari 35 orang laki - laki dan 32 perempuan. Kartu Aku dimiliki oleh 27 responden laki - laki dan 40 responden perempuan. Sedangkan kartu Yomart Card dimiliki oleh 6 orang laki - laki dan 3 orang perempuan. Bila dilihat dari jumlah kepemilikan kartu, hasil dari penelitian ini menunjukkan jumlah kepemilikan kartu membership card minimarket terbanyak adalah 2 buah kartu. Dari hasil kuisioner menujukkan bahwa 28 responden memiliki 2 buah kartu keanggotaan aktif pada peritel minimarket yang berbeda. Terdapat 20 orang responden perempuan yang memiliki 2 buah kartu keanggotaan aktif. Konsumen menggunakan lebih dari 1 kartu karena responden berbelanja di lebih dari 1 minimarket serta karena setiap kartu memberikan manfaat yang berbeda. Kepemilikan membership card pada responden perempuan mencerminkan adanya sikap multi-loyalty yang lebih besar dibandingkan konsumen laki-laki.

Sebanyak 48 responden $(42 \%)$ mengunjungi minimarket sebanyak 3 - 4 kali per bulan. 34 orang responden (29\%) mengunjungi minimarket lebih dari 6 kali per bulan,17 responden (15\%) mengunjungi 5 - 
6 kali per bulan dan 16 responden (15\%) mengunjungi minimarket sebanyak $1-2 \mathrm{kali}$ setiap bulannya. Data menunjukkan bahwa sebagian besar pemilik kartu mengunjungi minimarket minimal sekali dalam seminggu.

Sebanyak 37 responden (32\%) menghabiskan Rp. 20.000 - 50.000 pada setiap kunjungannya ke gerai minimarket. Sebanyak 31 responden (27\%) menghabiskan Rp. 50.001 - 80.000 setiap kunjungan, sebanyak 10 responden (9\%) mengeluarkan uang sebanyak Rp. 80.001 120.000. 10 orang responden $(9 \%)$ berbelanja rata - rata senilai Rp. 120.001 150.000 sedangkan 13 responden (11\%) membelanjakan uang mereka rata - rata senilai lebih dari Rp.150.000.

\subsection{Uji Reliabilitas}

Uji Reliabilitas adalah suatu pengukuran yang menunjukkan sejau mana pengukuran tersebut bebas dari kesalahan sehingga menjamin pengukuran yang konsisten lintas waktu dan lintas beragam item dalam instrumen (Sekaran, 2006). Uji reliabilitas akan menunjukkan stabilitas dan konsistensi alat ukur yang digunakan.

Salah satu metode uji reliabilitas untuk uji skala parametrik adalah metode Alpha-Cronbach. Menurut Arikunto (1998), penggunaan Teknik Alpha-Cronbach akan menunjukkan bahwa suatu instrumen dapat dikatakan handal (reliabel) bila memiliki koefisien reliabilitas atau alpha sebesar 0,6 atau lebih. Pengujian reliabilitas menggunakan rumus Alpha Cronbach, dengan ketentuan sebagai berikut :

a. Jika koefisien alpha $\geq 0,6$ maka item variabel tersebut dinyatakan reliable.

b. Jika koefisien alpha $<0,6$ maka item variabel tersebut dinyatakan tidak reliable.

Variabel card satisfaction $\left(\mathrm{X}_{1}\right)$ dalam penelitian ini menunjukkan koefisien Alpha Cronbach sebesar 0,789 lebih besar dari angka alpha maka indikator variabel card satisfaction $\left(\mathrm{X}_{1}\right)$ adalah reliable.

Variabel Card Perceived Value $\left(\mathrm{X}_{2}\right)$ menunjukkan koefisien Alpha Cronbach sebesar 0,757 lebih besar dari angka alpha maka indikator variabel Card Perceived Value $\left(\mathrm{X}_{2}\right)$ adalah reliable.

Variabel Card Loyalty $\left(\mathrm{Y}_{1}\right.$ atau $\left.\mathrm{X}_{3}\right)$ dalam penelitian ini menunjukkan koefisien Alpha Cronbach sebesar 0,654 lebih besar dari angka alpha maka indikator variabel Card Loyalty $\left(\mathrm{Y}_{1}\right.$ atau $\mathrm{X}_{3}$ ) adalah reliable.

Variabel Store Satisfaction $\left(\mathrm{X}_{4}\right)$ dalam penelitian menunjukkan koefisien Alpha Cronbach sebesar 0,668 lebih besar dari angka alpha maka indikator variabel Store Satisfaction $\left(\mathrm{X}_{4}\right)$ adalah reliable.

Variabel Store Loyalty $\left(\mathrm{Y}_{2}\right)$ dalam penelitian ini menunjukkan koefisien Cronbach Alpha sebesar 0,658 lebih besar dari angka alpha maka indikator variabel Store Loyalty $\left(\mathrm{Y}_{2}\right)$ adalah reliable.

\subsection{Uji Validitas}

Uji validitas dilakukan untuk mengetahui tingkat ketepatan alat ukur dalam mengungkap sebuah konsep. Pengujian dilakukan terhadap jawaban yang diperoleh dari responden terhadap alat ukur yang digunakan (Sekaran, 2006).

Salah satu metode pengukuran validias adalah perhitungan korelasi product moment. Hasil dari perhitungan ini adalah membandingkan koefisien Pearson dengan nilai $r_{\text {tabel }}$ pada taraf siginifikan 0,05 atau 0,01. Apabila koefisien Pearson lebih besar dari pada nilai $r_{\text {tabel }}$ maka variabel yang dihitung dapat dinyatakan valid.

$\begin{array}{ccc}\text { Uji } & \text { validitas terhadap } & \text { semua } \\ \text { indikator pengukuran variabel card }\end{array}$ satisfaction $\left(\mathrm{X}_{1}\right)$, menunjukkan koefisien validitas berkisar antara 0,517 hingga 0,649. Nilai $r_{\text {tabel }}$ pada $\alpha=0,01$ adalah sebesar 0,256 . Nilai koefisien validitas lebih besar dari nilai $r_{\text {tabel, }}$, pertanyaan no 3 hingga 7 yang 
digunakan pada kuisioner penelitian dinyatakan valid untuk mengukur variabel card satisfaction.

Semua indikator pengukuran variabel card perceived value $\left(\mathrm{X}_{2}\right)$, menunjukkan koefisien validitas berkisar antara 0,378 hingga 0,666 . Nilai $r_{\text {tabel }}$ pada $\alpha$ $=0,01$ adalah sebesar 0,256 . Nilai koefisien validitas lebih besar dari nilai $r_{\text {tabel }}$, semua indikator pengukur variabel card perceived value dapat dinyatakan valid.

Uji validitas terhadap semua indikator pengukuran variabel card loyalty $\left(\mathrm{Y}_{1}\right.$ atau $\left.\mathrm{X}_{3}\right)$, menunjukkan koefisien validitas berkisar antara 0,339 hingga 0,539.

Nilai $r_{\text {tabel }}$ pada $\alpha=0,01$ adalah sebesar 0,256 . Nilai koefisien validitas lebih besar dari nilai $r_{\text {tabel, }}$ semua indikator pengukur variabel card loyalty dapat dinyatakan valid.

Hasil uji validitas terhadap semua indikator pengukuran variabel store satisfaction $\left(\mathrm{X}_{3}\right)$, menunjukkan koefisien validitas berkisar antara 0,419 hingga 0,560. Nilai $r_{\text {tabel }}$ pada $\alpha=0,01$ adalah sebesar 0,256 . Nilai koefisien validitas lebih besar dari nilai $r_{\text {tabel, }}$ pertanyaan no 8 hingga 10 yang digunakan pada kuisioner penelitian dinyatakan valid untuk mengukur variabel store satisfaction.

Hasil uji validitas terhadap semua indikator pengukuran variabel store loyalty $\left(\mathrm{Y}_{2}\right)$, menunjukkan koefisien validitas berkisar antara 0,365 hingga 0,542 . Nilai $r_{\text {tabel }}$ pada $\alpha=0,01$ adalah sebesar 0,256 . Nilai koefisien validitas lebih besar dari nilai $r_{\text {tabel, }}$ semua indikator pengukur variabel store loyalty dapat dinyatakan valid.

\subsection{Analisa Regresi}

Pengaruh variabel Card Satisfaction dan Card Perceived Value terhadap Card loyalty dapat dilihat dari formula :

$\mathrm{Y}_{1}=1.132+0.204 \mathrm{X}_{1}+0.317 \mathrm{X}_{2}$

Berdasarkan persamaan regresi diatas maka menunjukkan bahwa koefisien variabel $X_{1}$ sebesar 0,204 dan koefisien variabel $X_{2}$ sebesar 0,317 . Dengan besar nilai koefisien $\mathrm{X}_{1}$ dan $\mathrm{X}_{2}$ maka dapat dijelaskan bahwa card satisfaction dan card perceived value berpengaruh positif terhadap card loyalty dengan besar pengaruh yang berbeda. Hasil penelitian menunjukkan bahwa card perceived value mempunyai pengaruh lebih besar terhadap card loyalty dibandingkan dengan card satisfaction.

Hasil penelitian menunjukkan bahwa untuk meningkatkan card loyalty, akan lebih efektif bagi perusahaan untuk memperhatikan perceived value yang positif dalam benak konsumen. Tindakan tersebut akan lebih efektif dari pada hanya memperhatikan kepuasan terhadap program semata.

Pengaruh Variabel Store Satisfaction dan Card Loyalty terhadap Store loyalty dapat dilihat dari formula regresi : $\mathrm{Y}_{2}=0.535+0.509 \mathrm{X}_{3}+0.288 \mathrm{X}_{4}$

Berdasarkan persamaan regresi diatas maka menunjukkan bahwa koefisien variabel $\mathrm{X}_{3}$ sebesar 0,509 dan koefisien variabel $\mathrm{X}_{4}$ sebesar 0,288 . Dengan melihat besar nilai koefisien $\mathrm{X}_{3}$ dan $\mathrm{X}_{4}$ maka dapat dijelaskan bahwa card loyalty dan store satisfaction berpengaruh positif terhadap store loyalty dengan besar pengaruh yang berbeda. Card loyalty mempunyai pengaruh lebih besar terhadap store loyalty dibandingkan dengan store satisfaction.

Dalam persaingan yang ketat dalam industri ritel kategori minimarket, perusahaan perlu memperhatikan program membership card. Penelitian ini menunjukkan bahwa card loyalty memiliki pengaruh positif yang lebih besar terhadap store loyalty. Dengan demikian, perusahaan selain berupaya untuk memuaskan konsumennya, perlu juga berupaya untuk meningkatkan loyalitas konsumennya terhadap program membership card yang dimiliki. 


\subsection{Korelasi dan Koefisien Determinan}

Tingkat kekuatan hubungan antara card satisfaction dan card loyalty memiliki nilai koefisien korelasi (r) sebesar 0,412 sedangkan hubungan antara card perceived value dan card loyalty memiliki nilai koefisien korelasi (r) sebesar 0,451 dengan nilai $\mathrm{P}$ Value 0,000 , karena nilai $\mathrm{P}$ Value $\leq$ 0,01 maka ini menunjukkan ada hubungan yang kuat antara card satisfaction dan card perceived value terhadap card loyalty.

Hasil penelitian ini serupa dengan kesimpulan penelitian yang dilakukan oleh Yang dan Peterson (2004) menyatakan bahwa perusahaan berjuang untuk memperoleh loyalitas pelanggan harus memiliki fokus utama pada customer satisfaction dan customer perceived value.

Koefisien determinan (Adjusted $R$ Square) sebesar 0,213 atau sebesar 21\%. Hal ini berarti sebesar $21 \%$ variasi yang terjadi pada variabel Card Loyalty $\left(\mathrm{Y}_{1}\right)$ dapat dijelaskan oleh variabel independen yaitu Card Satisfaction $\left(\mathrm{X}_{1}\right)$ dan Card Perceived Value $\left(\mathrm{X}_{2}\right)$. Dan sisanya (100\% $21 \%=79 \%$ ) dijelaskan oleh sebab-sebab yang lain di luar variabel $\mathrm{X}_{1}$ dan $\mathrm{X}_{2}$.

Tingkat kekuatan hubungan antara card loyalty dan store loyalty memiliki nilai koefisien korelasi (r) sebesar 0,576 sedangkan hubungan antara store satisfaction dan store loyalty memiliki nilai koefisien korelasi (r) sebesar 0,407 dengan nilai $\mathrm{P}$ Value 0,000 , karena nilai $\mathrm{P}$ Value $\leq$ 0,01 maka ini menunjukkan ada hubungan yang kuat antara card loyalty dan store satisfaction terhadap store loyalty.

Koefisien determinan (Adjusted $R$ Square) sebesar 0,411 atau sebesar $41 \%$. Hal ini berarti sebesar $41 \%$ variasi yang terjadi pada variabel Store Loyalty $\left(\mathrm{Y}_{2}\right)$ dapat dijelaskan oleh variabel independen yaitu Card Loyalty $\left(\mathrm{X}_{3}\right)$ dan Store
Satisfaction $\left(\mathrm{X}_{4}\right)$. Dan sisanya $(100 \%$ - $41 \%$ $=59 \%$ ) dijelaskan oleh sebab-sebab yang lain diluar variabel $\mathrm{X}_{3}$ dan $\mathrm{X}_{4}$.

\subsection{Harapan Konsumen Terhadap Program Membership Card \\ Manfaat yang paling diinginkan oleh} responden adalah promosi khusus untuk member. Promosi yang paling diinginkan adalah potongan harga atas pembelanjaan yang dilakukan menggunakan membership card. Selain promosi, responden juga mengharapkan membership card yang dapat digunakan sebagai alat pembayaran.

Sebagai alat pembayaran, responden menginginkan proses transaksi yang lebih cepat dibandingkan dengan pembayaran secara tunai. Apabila membership card dapat digunakan sebagai alat pembayaran, responden mengaharapkan agar kartu yang dimiliki bukan hanya dapat dipakai membayar belanja konsumen namun juga dapat dipakai di merchant lainnya.

Sebagai anggota dari program membership, responden berharap mendapatkan privilege dibandingkan konsumen yang tidak menjadi anggota program membership. Hak istimewa yang diharapkan oleh responden adalah memperoleh prioritas antrian saat berbelanja. Selain diprioritaskan dalam antrian, responden juga berharap bisa mendapatkan informasi lebih awal mengenai promosi dan produk baru yang akan diadakan di minimarket.

\subsection{Dampak Membership Card terhadap Tindakan Konsumen}

Kepemilikan terhadap membership card bisa mempengaruhi konsumen untuk membeli produk home brand. Produk home brand biasanya memberikan kontribusi margin yang lebih tinggi dibandingkan produk lainnya bagi peritel. 
Salah satu indikator dari sikap loyal terhadap gerai peritel, adalah menjadikan gerai tersebut sebagai pilihan pertama dalam berbelanja. Hasil penelitian menujukkan bahwa $46 \%$ responden menjadikan peritel penyedia program membership sebagai pilihan pertamanya dalam berbelanja.

$42 \%$ Responden berpendapat bahwa kepemilikan terhadap membership card mendorong mereka untuk berbelanja lebih banyak. 39\% responden mau untuk merekomendasikan program membership card kepada orang lain. $41 \%$ responden setuju untuk merekomendasikan minmarket tempat mereka menjadi anggota kepada orang lain. Memberikan rekomendasi (word of mouth) merupakan salah satu indikator dari adanya loyalitas. Keinginan untuk berbelanja lebih banyak serta merekomendasikan kepada orang lain merupakan ciri dari loyalitas yang dimiliki oleh konsumen (Bloemer, et al., 1998) (Foster dan Cadogan 2000).

Kepemilikan terhadap membership card dapat mempengaruhi loyalitas konsumen. 59\% responden merasakan adanya manfaat ekonomis dari memiliki membership card. Manfaat ekonomis merupakan salah satu aspek yang dipertimbangkan konsumen dalam pembentukan perceived value dalam benaknya. Dalam penelitian Lin and Wang (2006) ditunjukkan hasil bahwa perceived value merupakan salah satu antecedent loyalitas.

\section{KESIMPULAN REKOMENDASI}

DAN

\subsection{Kesimpulan}

Kesimpulan yang dapat diambil dari penelitian ini adalah sebagai berikut :

1. Card satisfaction dan card perceived value memberikan pengaruh positif pada card loyalty. Dari hasil tersebut dapat disimpulkan bahwa untuk dapat memperoleh card loyalty dari konsumen, perusahan perlu mengupayakan kepuasan pelanggan serta menciptakan perceived value yang positif. Card Perceived value memiliki pengaruh yang lebih besar dibandingkan card satisfaction terhadap card loyalty.

2. Card loyalty dan store satisfaction baik memiliki pengaruh positif terhadap store loyalty. Card Loyalty memiliki pengaruh yang lebih besar dibandingkan card satisfaction terhadap store loyalty.

3. Hasil dari penelitian ini mengungkapkan bahwa konsumen banyak mengharapkan membership card yang juga dapat digunakan sebagai alat pembayaran. Serta memperoleh privilege dalam antrian dan informasi promosi.

4. Hasil penelitian menunjukkan bahwa $25 \%$ dari responden memiliki lebih dari 1 kartu keanggotaan. Kondisi ini menunjukkan keberadaan multi-loyalty pada konsumen minimarket di Jakarta.

\subsection{Rekomendasi}

Rekomendasi yang dapat diberikan dari kesimpulan di atas adalah sebagai berikut :

1. Untuk meningkatkan loyalitas pelanggannya, perusahaan perlu meningkatkan card loyalty. Hasil penelitian menunjukkan bahwa card loyalty memiliki pengaruh yang lebih besar dibandingkan store satisfaction dalam meningkatkan store loyalty.

2. Dalam upaya meningkatkan card loyalty, perusahan harus fokus dalam menciptakan value yang bermanfaat kepada konsumen. Dengan penambahan value yang lebih besar dari pada biaya yang harus dikeluarkan konsumen, maka card loyalty dapat ditingkatkan.

3. Memberikan perceived value yang positif pada konsumen dengan memberikan 
privilege seperti : jalur antrian khusus bagi member, informasi penawaran promosi sebelum promosi di jalankan kepada seluruh konsumen melalui media komunikasi elektronik seperti e-mail dan pesan sms. Peritel dapat memperkaya manfaat dari membership card melalui kerja sama dengan berbagai merchant.

4. Peritel minimarket perlu menciptakan sarana komunikasi yang interaktif antara peritel dengan anggota. Melalui media yang interaktif, dapat dilakukan survey berkala terhadap anggota membership card program sehingga senantiasa memahami keinginan dan kebutuhan konsumen.

5. Peritel minimarket perlu meningkatkan kecepatan proses transaksi pembayaran dengan menggunakan membership card. Dengan demikian, konsumen akan merasakan bahwa pembayaran menggunakan membership card lebih praktis dari pada pembayaran tunai ataupun metode lainnya.

6. Di masa mendatang, penelitian ini dapat dikembangkan untuk memberikan lebih banyak manfaat secara akademik maupun aplikasi praktis. Untuk pengembangan penelitian ini, dapat dilakukan dengan memperluas sample serta membandingkan antara loyalitas anggota program membership card dengan konsumen yang tidak menjadi anggota. Studi lintas-daerah dapat dilakukan untuk memeriksa kemampuan generalisasi dari model ini. Penelitian di masa depan dapat dikembangkan dengan mempertimbangkan persaingan antar program loyalitas seperti penelitian yang pernah dilakukan oleh Meyer-Waarden pada tahun 2007, customer involvement dan waktu pemberian reward dari membership card (Sunny Hu et al., 2010). 


\section{DAFTAR PUSTAKA}

Aaker, J.L. 1997. "Dimensions of brand personality". Journal of Marketing Research. Vol. 34 No. 3, pp. 347-57.

Bhattacharya, C. B. 1998. "When customers are members: Customer retention in paid membership context". Journal of Academy of Marketing Science 26 (1): 31-44.

Bloemer, Josee, Ko de Ruyter dan Pascal Peeters. 1998. "Investigating Drivers of Bank Loyalty : The Complex Relationship Between Image, Service, Quality and Satisfaction", International Journal of Bank Marketing,Vol.16, No.7

Buttle, Francis. 2004. Customer Relationship Management Concepts and Tools. Italy : Elsevier Butterwirth-Heinemann Publications.

Chaudhuri, A. dan Holbrook, M.B. 2001, "The chain of effects from brand trust and brand affect to brand performance: the role of brand loyalty". Journal of Marketing. Vol. 65 No. 2, pp. $81-93$

Dick, A.S. dan Basu, K. 1994. "Customer loyalty: toward an integrated conceptual framework".Journal of the Academy of Marketing Science. Vol. 22 No. 2, pp. 99-113.

Dowling, Grahame R. dan Mark Uncles. 1997. "Do Customer Loyalty Programs ReallyWork?." Sloan Management Review 38 (Summer): 71-82.

Ehrenberg, A. S. C. 1988. Repeat-Buying: Facts, Theory, and Applications. 2d ed. London: Charles Griffin

Foster, Brian D dan John Q, Cadogan. 2000, "Relationship Selling and Costumer Loyalty : An Empirical Investigation". Marketing Investigation and Planning 18/4

Griffin, Jill, .2002. Customer Loyalty : How to Earn It, How to Keep It. Singapore : The Free Press.

Gronroos, C. 2000. Service Management and Marketing, A Csutomer Relationship Management Approach $\left(2^{\text {nd }}\right.$ ed). West Sussex: Chichester.

Hanan, Mack dan Peter Karp. 1991. Customer Satisfaction: How to Maximaze, Measure and Market your company's Ultimate Product. New York: American Management Association.

Junaidi, Shellyana dan Basu Swastha Dharmmesta. 2002. "Pengaruh Ketidakpuasan Konsumen, Karakteristik Kategori Produk, dan Kebutuhan Mencari Variasi Terhadap Keputusan Perpindahan Merek". Jurnal Ekonomi dan Bisnis Indonesia. Vol. 17, No. 1, pp. 91 - 94

Liu, Y. dan Yang, R. 2009. "Competing loyalty programs: Impacts of market saturation, market share and category expandability. Journal of Marketing, 73, 93-108.

Lin, H. H., dan Y. S. Wang. 2006. An examination of the determinants of customer loyalty in mobile commerce contexts. Information \& Management 43 (April): 271-282.

Liebermann, Y. 1999. "Membership clubs as a tool for enhancing buyers' patronage". Journal of Business Research. Vol. 45 No. 3, pp. 291-7.

Mägi, Anne W. 2003. "Share of Wallet in Retailing: The Effects of Customer Satisfaction, Loyalty Cards and Shopper Characteristics". Journal of Retailing. 79 (2), 97-106.

Merlin, Stone. 2004. "Henry Stewart Publications" 1479-1862 Vol. 12, 3, 305-318. Journal of Targeting, Measurement and Analysis for Marketing.

Mohsan, F. , Nawaz M. M. , Khan M. S. , Shaukat Z. , dan Aslam N. 2004. "Impact of Customer Satisfaction on Customer Loyalty and Intentions to Switch: Evidence from Banking Sector 
of Pakistan". International Journal of Business and Social Science Vol. 2 No. 16; September 2011.

Nunes, Joseph C dan Xavier Dreae. 2008. "Your loyalty program is betraying you". Harvard Business Review on Retail and Merchandising.

Kotler, Philip dan Keller. 2009. Manajemen Pemasaran. Edisi 13 Jilid 1. Jakarta.

Oliver, Richard L.1998. "Whence Customer Loyalty". Journal of Marketing. Vol.63 (Special Issues)

Parasuraman, A. V. A Zeithaml dan LL Berry. 1988. "SERVQUAL : A Multiple Item Scale for Measuring Consumer Peceptions of Service Quality". Journal of Retailling Vol.64 No.1

Passingham, J. 1998. "Grocery retailing and the loyalty card" Journal of the Market Research Society. Vol. 40 No. 1, pp. 55-63.

Reichheld, F. 1996. The Loyalty Effect. Boston, MA : HBS Press.

Reichheld, F.F., Markey, R.G. dan Hopton, C. 2000. "The loyaltyeffect-the relationship between loyaltyand profits". European Business Journal. Vol. 12 No. 3, pp. 134-9.

Sharp, B. dan Sharp, A. 1997. "Loyalty programs and their impact on repeat-purchase loyalty patterns". International Journal of Research in Marketing. Vol. 14 No. 5, pp. 473-86.

Sunny Hu, H.-H., Huang, C.-T. dan Chen, P. T. 2010.” Do reward programs truly build loyalty for lodging industry?". International Journal of Hospitality Management. 29, 128-135

Sweeney , J . C . dan Soutar , G . N . 2001 . "Consumer perceived value: The development of a multiple item scale". Journal of Retailing . 77 , 203 - 220 .

Uncles , M . D ., Dowling , G . R . dan Hammond K . 2003 . "Customer loyalty and customer loyalty programs". Journal of Consumer Marketing . 20 (4) , 294 - 316.

Yang, Zhilin dan Peterson, Robin T. 2004. "Customer Perceived Value, Satisfaction, and Loyalty: The Role of Switching Costs”. Psychology \& Marketing. Vol. 21(10):799-822, pp 818.

Yim, Chi Kin dan P. K. Kannan. 1999. "Cunsumer Behavioral Loyalty:A Segmentation Model and Analysis". Journal of Business Research 44:75-92

Youjae Yi dan Hoseong Jeon. 2003. "Effects of Loyalty Programs on Value Perception, Program Loyalty, and Brand Loyalty". Journal of the Academy of Marketing Science. 2003; 31; 229. 